\title{
Skateboard Injuries in a Campus Community
}

\author{
STANLEY H. SCHUMAN, M.D., DR.P.H.*
}

$\mathrm{L}$ communities we mania called "skateboarding." 1 Certain features of the sport, namely: (a) timing, and (b) extent and patterns of skateboard injury, seemed to lend themselves to an epidemiological approach.

a. Timing of the sport and its impact on this campus community was literally no accident! Many of the classic features of an acute infectious process were simulated, including an explosive "common-source" epidemic curve (Figs. 1, 2, 3).5 Agent-hostenvironment relationships were also quite analogous:

$$
\begin{aligned}
& \text { Agent- the profiteering dealer } \\
& \text { who sold the first } 500 \\
& \text { skateboards to sororities } \\
& \text { as spring party favors; } \\
& \text { the pool of susceptibles } \\
& \text { among exam-stressed stu- } \\
& \text { dents; } \\
& \text { Hosts- } \\
& \text { Environment-the enticement of a late } \\
& \text { but balmy spring; many } \\
& \text { paved hilly slopes, glam- } \\
& \text { orous advertising, and an } \\
& \text { ample supply of skate- } \\
& \text { boards. }
\end{aligned}
$$
Hosts- the pool of susceptibles among exam-stressed stu- dents;

b. Extent of injury tended to be exaggerated or minimized by partisans, although the severity of cases seen by orthopedic surgeons was well-documented." Two popula-

* Associate Professor, Epidemiology, School of Pub. lic Health, The University of Michigan, Ann Arbor, Michigan.

Paper prepared for Research Symposium on Child Safety, April 21-22, 1966. University of Virginia School of Medicine (Prof. R. J. Meyer), Charlottesville, Virginia. tion surveys were made to estimate morbidity:

1. A study of admissions for falls in 21 midwestern hospitals reporting to the Professional Activity Study (PAS). There was a considerable increase in hospitalizations of youngsters for falls in 1965 compared with two preceding years in a large sample of hospitals (Fig. 4). This evidence is circumstantial because specific skateboard etiology was not coded; nonetheless, the data are impressive be cause of the relatively low rates of hos.

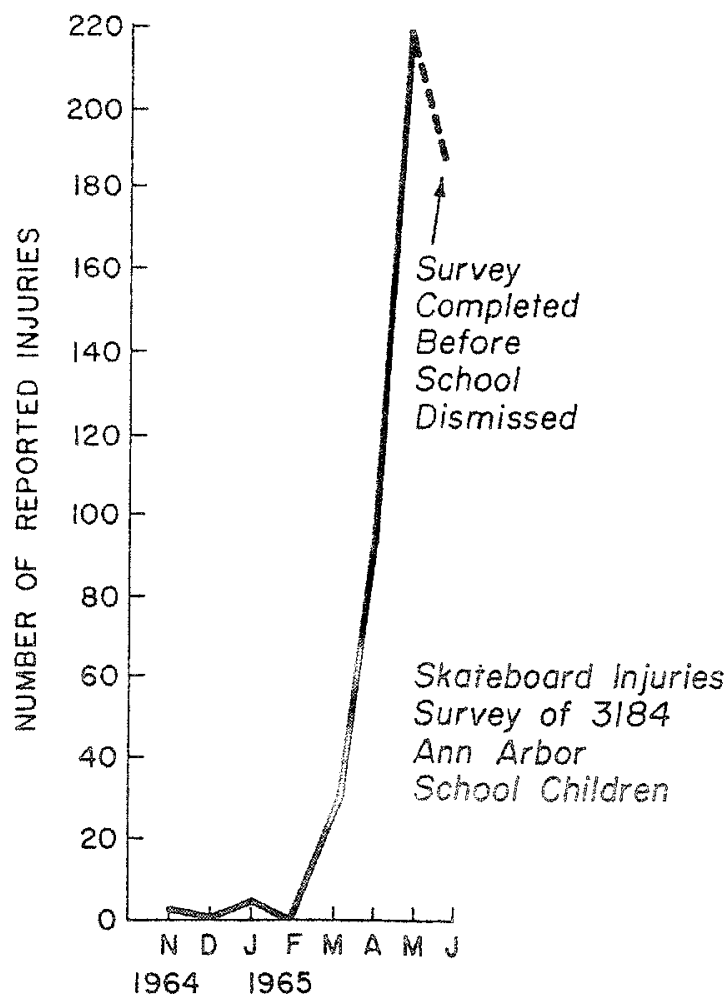

Fic. 1. Skateboard injuries survey of 3,184 Ann Axbor school children. 


\section{SKATEBOARD INJURIES}

pitalization from skateboard injury indicated from the school survey.

2. A questionnaire survey of 3,184 Ann Arbor schoolchildren, conducted in six schools in June, 1965. Although ages ranged from seven to 17 years, the emphasis was on reaching the junior high school group, whose responses to the questionnaires approached 85 per cent (Table 1). Onset of school vacation prevented any serious validation of the questionnaire; the results are presented. for patterns suggesting further more precise study.

It is not surprising that 16 of 21 fractures reported $(77 \%)$ were in boys, nor that the numbers of reported injuries correlated very well with the number of times skateboards were used. In contrast.

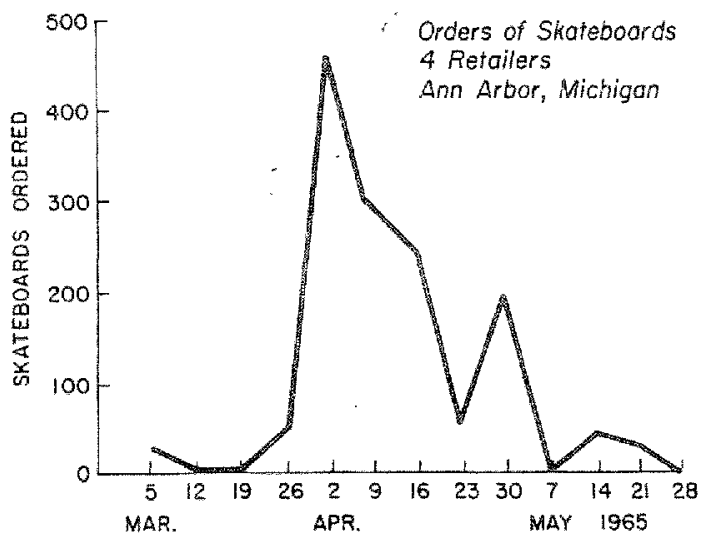

Fic. 2. Orders of skateboards, four retailers, Ann Arbor, Michigan.

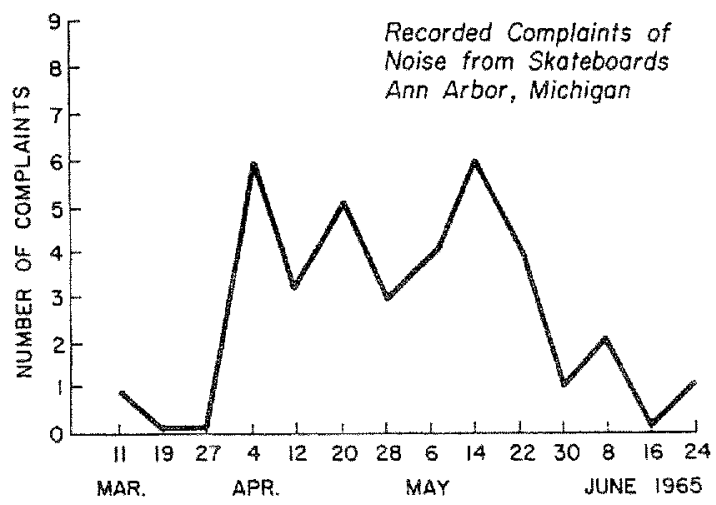

Fic. 3. Recorded complaints of noise from skateboards, Ann Arbor, Michigan.

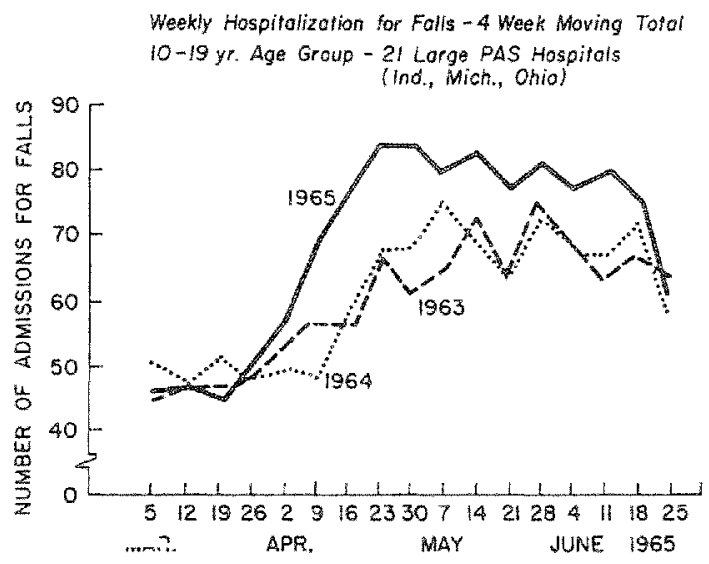

Fig. 4. Weekly hospitalization for falls-four week moving total.

to the high rate of injury $(24.8 \%)$, less than 1 per cent of skateboarders received fractures. Only 2.7 per cent of the injuries required professional treatment.

TABLE 1. Results of Survey of Ann Arbor Schoolchildren, June, 1965

\begin{tabular}{|c|c|c|c|c|c|c|c|}
\hline \multirow{2}{*}{$\begin{array}{l}\text { Age in } \\
\text { Years }\end{array}$} & \multicolumn{4}{|c|}{ Number } & \multirow{2}{*}{$\begin{array}{l}\text { Exposure: } \\
\text { Average } \\
\text { Person- } \\
\text { Times }\end{array}$} & \multirow{2}{*}{$\begin{array}{l}\text { Proportion: } \\
{\left[\frac{\text { Fractures }}{\text { Injured }}\right]}\end{array}$} & \multirow{2}{*}{$\begin{array}{l}\text { Proportion: } \\
{\left[\frac{\text { Fractures }}{\text { Skaters }}\right]}\end{array}$} \\
\hline & Respondents & Skaters & Injured & Fractures* & & & \\
\hline 9 & 151 & 93 & 21 & 1 & 4.9 & 0.05 & 0.01 \\
\hline 10 & 192 & 142 & 32 & 3 & 5.3 & 0.09 & 0.02 \\
\hline 11 & 205 & 151 & 45 & 4 & 5.4 & 0.09 & 0.03 \\
\hline 12 & 190 & 156 & 4.3 & 1 & 5.9 & 0.02 & 0.006 \\
\hline 13 & 675 & 570 & 166 & 5 & 6,0 & 0.03 & 0.01 \\
\hline 18 & 550 & 455 & 82 & 1 & 5.5 & 0.01 & 0.002 \\
\hline 15 & 511 & 417 & 105 & 4 & 5.7 & 0.04 & 0.01 \\
\hline Totals & 2,474 & 1,984 & 494 & $19^{*}$ & 5.65 & 0.039 & 0.01 \\
\hline Per cent & 100.0 & 80.0 & 24.8 & 0.96 & - & - & - \\
\hline
\end{tabular}

* Two additional fractures in ages 16 and 7 not listed here. Two additional fractures in age group 11 not listed, because they occurred 24 and 48 hours after the survey, according to teachers. 


\section{SCHUMAN}

4. Platform of hard finished wood $\left(20-30^{\prime \prime} \times 6-8^{\prime \prime} \times 1 / 2^{\prime \prime}\right)$

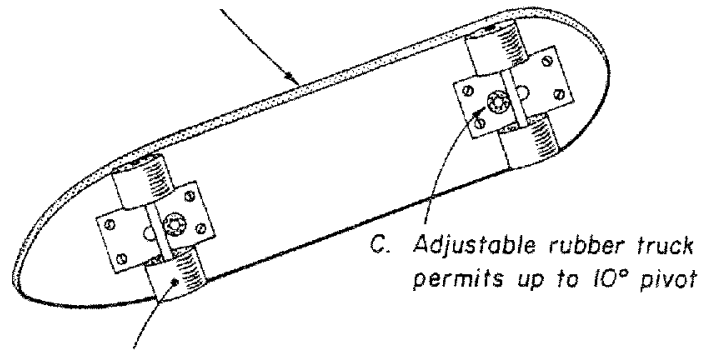

B. Ball-bearinged wheels - mounted in poirs (metal, rubber, plostic)

Fic. 5. Skateboard.

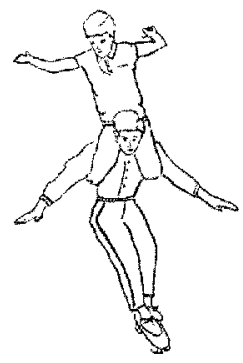

Stint

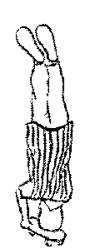

Headstand

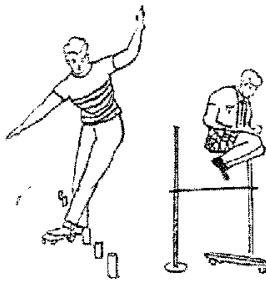
0

Hurding
Fic. 6. Skateboarding, Hilustrated.

Although small numbers limit the value of age-specific rates, it is evident from Table 1 that seven of 19 fractures occurred in the age groups ten and 11 ; thus 37 per cent of the fractures occurred in 15 per cent of the skateboarders. It is noteworthy that in another series of 33 skateboard fractures reported from another campus community, the two most severe fractures were in a boy aged Il (skull fracture) and a boy aged 12 (compound fracture) ${ }^{1}$

These data suggest that, even within a relatively narrow age group ( $9-15$ years), the hazards of skateboarding may not be equally distributed. As is well known, a year or two difference in chronologic age can make a significant difference in coordination and margins of safety. ${ }^{4}$ Risk-taking behavior, cheaper and inferior equipment, and other factors may contribute to injuries being more severe in ten- to 12-year-old boys than in those a little older.

\section{Acknowledgment}

The above data could not have been collected with. out the cooperation of the Ann Arbor School District, the University School, the Parochial Schools of Ann Arbor, and the Commission on Professional and Hospital Activities (P.A.S.).

\section{References}

1. Kincaid, C. K.: The high price of skateboarding. Quart. Bull., Wisc. State Board of Health 17: 9, 1965 .

2. Life Magazine, May 14, 1965, Cover and pp. 126-134. Skateboards-The craze, the menace.

3. Liver, $J$. A. and Viley, J. J.: Skurfing injuies. Canad. Med. Assn. J. 93: 651, 1965.

4. Pierson, W, K. and Montoye, H. J.: Yovement time, reaction time, and age. $J$. Geront. 13: 418, 1958.

5. Slee, V. N., Perlman, J. M., Schuman, S, H. and Leighton, E.: The potential of P.A.S. for epidemiologic research, read before the Epidemiology Section of the A.P.H.A. in Chicago, OCtober, 1965. 